\title{
China's Role in the Rising of the South: Vision for 2030
}

\section{Angang Hu, Yuning Gao, Yilong Yan and Xing Wei*}

\begin{abstract}
This article examines China's major development contributions, looking at its wider impact on world development. In particular, the article examines the impact of China's development on the changing pattern between the North and South and the human development index. The factors and related regimes behind these phenomena are discussed and a conceptual model is constructed, providing a meta-analysis of the evolution of China's role, based on the structural interpretation of external impetus and barriers, as well as internal advantages and shortcomings. The authors' long-term projections show that the rise of the South, led by China, will be the most important shift in the world's landscape with respect to the development of the emerging world, perhaps leading other large developing economies to play a more prominent role in international development in the future, bringing common development, common prosperity and common progress to the world.
\end{abstract}

中国在发展中国家崛起中发挥的作用: 展望 2030

胡鞍钢, 高宇宁, 鄢一龙, 魏星

本文通过分析中国对全球发展的广泛影响, 研究了中国对发展的主要贡献。本文重 点分析了中国发展对南北关系变化和人类发展指数的影响; 讨论了这些现象背后的 因素和相关制度，建立了概念模型，并基于对外部推动力和阻力以及内部优势和短 板的结构性阐释, 对中国影响的演变进行元分析。长期预测结果显示, 以中国为领 导的发展中国家的崛起将是世界格局最重要的变化, 可能会使其他发展中大国今后 在国际发展中发挥更重要的作用, 推动全球的共同发展、繁荣和进步。

IDS Bulletin Volume 45 Number 4 July 2014 (c) 2014 The Authors. IDS Bulletin (C) 2014 Institute of Development Studies Published by John Wiley \& Sons Ltd, 9600 Garsington Road, Oxford OX4 2DQ, UK and 350 Main Street, Malden, MA 02148, USA 
Table 1 World urban population percentages for the South and the North (1950-2030)

\begin{tabular}{lrrrrrrr}
\hline & $\mathbf{1 9 5 0}$ & $\mathbf{1 9 7 0}$ & $\mathbf{1 9 9 0}$ & $\mathbf{2 0 0 0}$ & $\mathbf{2 0 1 0}$ & $\mathbf{2 0 2 0}$ & $\mathbf{2 0 3 0}$ \\
\hline The South & $\mathbf{5 2 . 4}$ & $\mathbf{6 1 . 5}$ & $\mathbf{7 1 . 7}$ & $\mathbf{7 5 . 1}$ & $\mathbf{7 7 . 6}$ & $\mathbf{7 9 . 8}$ & $\mathbf{8 1 . 8}$ \\
China & 8.8 & 10.7 & 13.4 & 16.0 & 19.1 & 21.0 & 22.9 \\
India & 8.7 & 8.2 & 9.8 & 10.2 & 10.5 & 11.1 & 12.0 \\
Russia & 6.2 & 6.1 & 4.8 & 3.8 & 2.9 & 2.4 & 2.0 \\
Brazil & 2.7 & 4.0 & 4.9 & 5.0 & 4.9 & 4.5 & 4.0 \\
The North & 47.6 & 38.5 & $\mathbf{2 8 . 3}$ & $\mathbf{2 4 . 9}$ & $\mathbf{2 2 . 4}$ & $\mathbf{2 0 . 2}$ & $\mathbf{1 8 . 2}$ \\
USA & 13.9 & 11.6 & 8.5 & 8.0 & 7.5 & 7.0 & 6.6 \\
EU & 21.5 & 16.1 & 11.2 & 9.2 & 8.2 & 7.3 & 6.5 \\
Japan & 4.0 & 4.2 & 3.4 & 2.9 & 2.4 & 2.1 & 1.7 \\
\hline
\end{tabular}

Note The North refers to advanced economies as defined by the International Monetary Fund (IMF). They include 34 countries; the EU includes 27 countries; the South refers to countries that are not included in the North.

Source Authors' own with data from Population Division of the Department of Economic and Social Affairs of the United Nations Secretariat (2010); data for China were sourced from the national population census from various years.

\section{Introduction}

In the decades after the Second World War, especially since the end of the Cold War in 1990, the rise of the South has become increasingly apparent. Generally speaking, the North usually refers to the developed world with the highest income level, which has dominated global economic output since the industrial revolution. In contrast, the rising of the South is quite recent, driven by the emerging economies.

Among the emerging economies, China is clearly the most significant rising power, being already the second largest economy in the world. Most research has focused on the overall amount of China's economic output, its labour force, investment and trade, together with the challenge it faces in terms of energy consumption and carbon emission. This article not only highlights China's contribution to the rise of the South in these fields, but also discusses China's contribution in terms of poverty alleviation, especially from the perspective of income and the Human Development Index (HDI). This article focuses on the major trends outlined above and predicts the future development trends for both China and the world.

\section{The changing pattern of international development: rise of the South}

The structure of the global population will shift significantly from rural to urban, with an increasing rate of global urbanisation, which will reach 59 per cent by $2030 .{ }^{1}$ By that time, the South will contain 81.8 per cent of the urban population, while the North will be home to less than 20 per cent (see Table 1). Although the urbanisation rate is likely to slow, the annual average growth of the urban population will top 1 per cent. In this process, the cluster effect of urbanisation will become more obvious. A higher level of urbanisation means a larger consumer market, especially in the South, which will become a leading player in the growth of global consumption. By 2025, two billion people, or 25 per cent of the global population, will live in the world's 600 largest cities. These cities will create US\$64 trillion in gross domestic product (GDP), close to 60 per cent of global GDP. There will be 735 million families with an average annual income per capita of US $\$ 32,000$ in the 600 largest cities. Of these, 235 million families will be living in developing countries, with their per capita annual income at more than US\$20,000 (McKinsey Global Institute 2011). However, city slums are likely to become a factor influencing the quality of urbanisation development. This is a glaring problem facing the governments of all countries as they pursue their urbanisation strategies.

In the current golden age of economic development, there will be major changes in the global economic landscape. The economic strength of the South and the North will be 
Table 2 World total GDP (PPP) percentages for the South and the North (1820-2030)

\begin{tabular}{lrrrrrrrrr}
\hline & $\mathbf{1 8 2 0}$ & $\mathbf{1 8 7 0}$ & $\mathbf{1 9 1 3}$ & $\mathbf{1 9 5 0}$ & $\mathbf{1 9 7 3}$ & $\mathbf{2 0 0 0}$ & $\mathbf{2 0 1 0}$ & $\mathbf{2 0 2 0}$ & $\mathbf{2 0 3 0}$ \\
\hline The South & $\mathbf{7 0 . 3}$ & 53.1 & $\mathbf{4 2 . 1}$ & $\mathbf{3 9 . 5}$ & $\mathbf{3 9 . 9}$ & $\mathbf{4 3 . 0}$ & $\mathbf{5 2 . 4}$ & $\mathbf{6 0 . 5}$ & $\mathbf{6 6 . 9}$ \\
China & 33.0 & 17.1 & $\mathbf{8 . 8}$ & $\mathbf{4 . 6}$ & $\mathbf{4 . 6}$ & 11.8 & 20.7 & $\mathbf{2 8 . 9}$ & 33.4 \\
India & 16.1 & 12.2 & 7.5 & 4.2 & 3.1 & 5.2 & 8.0 & 12.2 & 18.6 \\
Russia & 5.4 & 7.5 & 8.5 & 9.6 & 9.4 & 2.1 & 2.4 & 2.7 & 3.0 \\
Brazil & 0.4 & 0.6 & 0.7 & 1.7 & 2.5 & 2.7 & 2.6 & 3.6 & 5.1 \\
The North & 29.7 & 46.9 & 57.9 & 60.5 & 60.1 & 57.0 & $\mathbf{4 7 . 6}$ & 39.5 & 33.1 \\
USA & 1.8 & 8.9 & 18.9 & 27.3 & 22.1 & 21.9 & 18.4 & 16.7 & 15.1 \\
EU & 23.3 & 32.0 & 35.8 & 27.1 & 27.1 & 21.5 & 18.1 & 15.7 & 13.1 \\
Japan & 3.0 & 2.3 & 2.6 & 3.0 & 7.8 & 7.2 & 5.4 & 4.4 & 3.2 \\
China/USA & 18.3 & 1.9 & 0.47 & 0.17 & 0.2 & 0.5 & 1.1 & 1.7 & 2.2 \\
\hline
\end{tabular}

Note GDP (PPP) is in 1990 international dollars.

Source Authors' own with data for 1820-2000 sourced from Maddison (2010); data regarding growth from 2010 to 2030 for the world and major economies are the estimates of the authors.

reversed. Not only will China and India return to 1820 levels by 2030, all countries of the South will return to 1820 levels, representing a classic U-turn.

The rapid rise of the South has meant that as of 2010 the GDP (measured by purchasing power parity (PPP) in 1990 constant price) of the South is now larger (52.4 per cent) than the North (47.6 per cent); this is an obvious change in the status quo where previously the North had dominated the world economic order. By 2030, the South could represent 66.9 per cent of countries and the North could be further reduced to 33.1 per cent. The South could dominate the world economy.

We are now at the mid-point of this period of growth. This trend is now commonplace worldwide, albeit accompanied by tributaries, with local counter-currents and we are seeing more and more countries becoming involved. Although this is now an irreversible worldwide trend, there may still be international financial crises.

Emerging economies have become a fresh motivating force behind global economic growth. China, in particular, is both the biggest beneficiary and the greatest supporter of the golden age of world economic development. From 2000 to 2030, countries with massive populations, such as Brazil, Russia, India, China and South Africa (BRICS), will become the central forces propelling global economic growth. By 2030, it is possible that the BRICS countries will have a combined economic aggregate representing 60.1 per cent of the world's total with that of China alone exceeding the combined total of the North (see Table 2).

In contrast, the economic aggregates of the USA, the EU and Japan will drop from 18.4 per cent, 18.1 per cent and 5.4 per cent, to 15.1 per cent, 13.1 per cent and 3.2 per cent, respectively. By 2030, the five biggest world economies will be those of China, India, the USA, the EU and Brazil. ${ }^{2}$

Emerging countries will play an increasingly important role in the international trade system, ending the long-term domination of the North. First, the factories of the world will be transferred from the North to the South. In 1870 , the ratio of international exports between the South and the North was essentially 30:70. In 2010, the ratio was 40:60. By 2030 it will be 70:30, by which point China's total exports will be close to a quarter of the world's total (see Table 3). Then, the world market will also be transferred from the North to the South. In 1950, the ratio of the South and the North in international imports was 30:70. By 2020 it will be $50: 50$, and $60: 40$ by 2030 , China's total imports will be more than a quarter of the world's total and China will be a net importer instead of net exporter (see Table 3). 
Table 3 Total global export percentages for the South and the North (1870-2030)

\begin{tabular}{lrrrrrrr}
\hline & $\mathbf{1 8 7 0}$ & $\mathbf{1 9 5 0}$ & $\mathbf{1 9 7 3}$ & $\mathbf{1 9 9 8}$ & $\mathbf{2 0 1 0}$ & $\mathbf{2 0 2 0}$ & $\mathbf{2 0 3 0}$ \\
\hline The South & $\mathbf{2 8 . 1}$ & $\mathbf{3 7 . 6}$ & $\mathbf{3 9 . 2}$ & $\mathbf{4 1 . 4}$ & $\mathbf{6 2 . 2}$ & $\mathbf{6 8 . 0}$ & $\mathbf{7 2 . 0}$ \\
China & 2.8 & 2.1 & 0.7 & 3.3 & 10.4 & 18.0 & 24.0 \\
India & 6.9 & 1.9 & 0.6 & 0.7 & 1.4 & 2.4 & 5.0 \\
Russia & 0.0 & 2.2 & 3.4 & 2.1 & 2.5 & 2.7 & 3.5 \\
Brazil & 1.7 & 1.2 & 0.6 & 0.9 & 1.3 & 1.7 & 2.9 \\
The North & 71.9 & 62.4 & 60.8 & 58.6 & 37.8 & 32.0 & $\mathbf{2 8 . 0}$ \\
USA & 5.0 & 14.6 & 10.3 & 12.8 & 8.4 & 10.0 & 9.0 \\
EU & 60.4 & 38.9 & 43.2 & 38.1 & 15.7 & 14.0 & 12.0 \\
Japan & 0.1 & 1.2 & 5.6 & 5.9 & 5.1 & 5.0 & 4.0 \\
\hline
\end{tabular}

Source Authors' own; data for 1820-2000 was sourced from Maddison (1995, 2001). 2020 and 2030 data are estimated by the authors based on international trade statistics.

In the international trade system, agricultural trade will increase but the percentage will continue to drop and service trades will rapidly increase, with the percentage of total international trade increasing from 20 per cent (currently) to approximately 30 per cent.

Trade liberalisation will remain a mainstream worldwide trend; however, this will be accompanied by a long-term conflict between trade liberalisation and trade protectionism. Country-specific trade friction cannot be avoided. There is even the possibility of an outbreak of local or regional trade wars, with the world powers being both interdependent and locked in such conflicts.

Until 2030, China will have a double role in world trade and investments: China will be transformed from a net exporter to a net importer; and from a net investment inflow country to a net outflow country. Since the Doha round of negotiations by the World Trade Organization (WTO), the environment and order of international trade has improved, and further improvements are expected. China's opportunities in the international trade system far outweigh any possible challenges. In the future trading system, the importers will be the winners. China will enjoy market advantages. Chinese transition from 'workshop' to 'market' will further strengthen the position and role of China in the international trade system.

From 2010 to 2030, global foreign direct investment (FDI) will maintain a steady growth rate, most likely the 3 per cent annual growth that has been registered since the beginning of the 1990s. Newly added foreign investments will mainly come from the emerging markets of China, India, Brazil and Russia. Global FDI will be characterised by the interaction between the

Table 4 World total FDI inflow volume percentages for the South and the North

\begin{tabular}{lrrrrrrr}
\hline & 1970 & 1980 & 1990 & 2000 & 2009 & 2020 & 2030 \\
\hline The South & 28.9 & 13.9 & 16.9 & 18.8 & 49.2 & 60.0 & 75.0 \\
China & 0.0 & 0.1 & 1.7 & 2.9 & 8.5 & 15.0 & 20.0 \\
The North & 71.1 & 86.1 & 83.1 & 81.2 & 50.8 & 40.0 & 25.0 \\
NAFTA & 25.4 & 45.9 & 28.2 & 28.5 & 14.5 & 10.0 & 10.0 \\
EU & 38.6 & 39.4 & 46.9 & 49.8 & 32.5 & 15.0 & 18.0 \\
\hline
\end{tabular}

Source Authors' own with data from UNCTAD (2011); data for 2020 and 2030 are the estimates of the authors. 


\begin{tabular}{lrrrrrr}
\hline & $\mathbf{1 9 8 0}$ & $\mathbf{2 0 0 0}$ & $\mathbf{2 0 0 7}$ & $\mathbf{2 0 1 5}$ & $\mathbf{2 0 2 0}$ & $\mathbf{2 0 3 0}$ \\
\hline The South & $\mathbf{4 4 . 0}$ & $\mathbf{4 7 . 6}$ & $\mathbf{5 4 . 2}$ & $\mathbf{5 9 . 5}$ & $\mathbf{6 2 . 1}$ & $\mathbf{6 5 . 4}$ \\
China & 8.3 & 11.0 & 16.4 & 20.6 & 22.1 & 22.8 \\
India & 2.9 & 4.6 & 5.0 & 5.7 & 6.2 & 7.7 \\
Latin America & 4.0 & 4.6 & 4.6 & 4.7 & 4.7 & 4.9 \\
The North & 56.0 & 52.4 & 45.8 & 40.5 & $\mathbf{3 7 . 9}$ & $\mathbf{3 4 . 6}$ \\
USA & 24.9 & 22.8 & 19.5 & 17.0 & 15.8 & 14.3 \\
EU & & 16.8 & 14.6 & 12.7 & 11.8 & 10.6 \\
Japan & 4.8 & 5.2 & 4.3 & 3.6 & 3.3 & 2.9 \\
\hline
\end{tabular}

Source Authors' own with data from International Energy Agency (2009); data for 2020 and 2030 are estimates based on an IEA model.

inflow and outflow of FDI, with a transition of investment from developed countries to developing countries and from developing countries to developed countries.

International capital will mainly flow into the South. From 2010 to 2030, the South will become the main destination for FDI. By 2030, 75 per cent of FDI will flow into the South (compared with approximately 20 per cent in 2000) (see Table 4). The South will become attractive to FDI because their labour and production costs are lower than in the North. In addition, the South will see improved levels of economic development, and higher average annual incomes. Market demand and market size will continue to expand and their investment conditions will also improve.

In terms of FDI reserves, the North will still occupy a dominant position but the South will be closing the gap. By 2030, the FDI reserves of the South will reach 40 per cent of the world's total while that of China will reach 8.0 per cent.

The FDI outflow of emerging economies (i.e. BRICS countries) will significantly increase; in 2008 it reached US $\$ 147$ billion, accounting for 9 per cent of the global FDI outflow. Only ten years earlier, it had measured 1 per cent (UNCTAD 2010). This value will continue to increase.

China will become the biggest foreign direct investor in the world. From 2002 to 2009, China's annual contribution to global FDI inflow was 3 per cent, with a global FDI outflow of 5.5 per cent. In recent years, China's foreign direct investment has increased more than eight times, from 0.5 per cent in 2002 to 4.4 per cent in 2009. China has become the fifth largest foreign direct investor. If calculated using a low GDP percentage of 5 per cent, China's FDI will increase by US $\$ 1$ trillion by 2020 . If the percentage rises to the level of 15 per cent such as in transitional economies, then Chinese foreign direct investment will reach approximately US $\$ 3$ trillion a year. We estimate that by 2030, China will become the world's number one foreign investor, with its outbound direct investment reaching approximately US $\$ 4.5-5$ trillion. China's outbound investment includes both China's interests overseas and the huge business opportunities and investment interests China provides to the world. In the future, China's gross national product (GNP) will exceed its GDP. However, international investment in China will continue while the era of China's international investments continues.

\section{The challenge of China's rise to the South and the world}

The global primary energy demand and consumption structure will experience a period of adjustment, starting with a transition to green energy sources. ${ }^{3}$ According to a prediction by the International Energy Agency (IEA), coal consumption will increase from 22.9 per cent in 2000 to 29.1 per cent by 2030; petroleum consumption will reduce from 36.5 per cent in 


\begin{tabular}{lrrrrrrrrr}
\hline & $\mathbf{1 8 2 0}$ & $\mathbf{1 8 7 0}$ & $\mathbf{1 9 1 3}$ & $\mathbf{1 9 5 0}$ & $\mathbf{1 9 7 3}$ & $\mathbf{2 0 0 0}$ & $\mathbf{2 0 1 0}$ & $\mathbf{2 0 2 0}$ & $\mathbf{2 0 3 0}$ \\
\hline The South & $\mathbf{8 . 1}$ & $\mathbf{2 0 . 8}$ & $\mathbf{2 7 . 0}$ & $\mathbf{3 4 . 7}$ & $\mathbf{4 7 . 8}$ & $\mathbf{5 8 . 4}$ & $\mathbf{6 4 . 0}$ & $\mathbf{7 0 . 3}$ & $\mathbf{7 4 . 1}$ \\
China & & & 0.3 & 1.3 & 5.7 & 13.7 & 23.8 & $\mathbf{2 8 . 3}$ & $\mathbf{2 8 . 3}$ \\
India & & & 1.0 & 1.1 & 1.3 & 4.8 & 5.4 & 6.6 & 8.4 \\
Latin America & & & 0.7 & 2.7 & 3.7 & 5.4 & 3.4 & 3.6 & 3.6 \\
The North & 91.9 & 79.2 & $\mathbf{7 3 . 0}$ & $\mathbf{6 5 . 3}$ & $\mathbf{5 2 . 2}$ & $\mathbf{4 1 . 6}$ & $\mathbf{3 6 . 0}$ & $\mathbf{2 9 . 7}$ & $\mathbf{2 5 . 9}$ \\
USA & 1.6 & 18.3 & 41.7 & 42.5 & 28.6 & 23.1 & 17.9 & 15.0 & 13.3 \\
EU & 90.3 & 60.6 & 26.7 & 17.4 & 14.7 & 10.0 & 12.2 & 9.8 & 8.3 \\
Japan & & & 1.6 & 1.7 & 5.9 & 4.9 & 3.8 & 3.2 & 2.7 \\
\hline
\end{tabular}

Source Authors' own: data for 1820-2000 are from Carbon Dioxide Information Analysis Center (2010); data for 2020-20 are estimates based on the data in International Energy Agency (2012).

2000 to 29.8 per cent by 2030 . Renewable energy sources such as nuclear energy, water energy and biological energy are expected to remain stable. During this period, all countries will be dedicated to developing green energy, and to the research and development (R\&D) of new energy technologies such as wind energy, solar energy and bio-energy. By 2030 the world will enter a crucial transition period regarding energy consumption. The production of global liquid hydrocarbon (such as petroleum and liquefied natural gas) will begin to decline. By that stage, it will be difficult to predict whether new energy technologies will be able to replace traditional energies (National Intelligence Council 2008).

The South will quickly become the main consumer of primary energy, with China in first place. The North will consume 34.6 per cent of primary energy sources, compared with 56 per cent in 1980. The South's primary energy consumption will jump from 44 per cent to 65.4 per cent. By 2030 China's primary energy demand will reach 22.8 per cent of the world's total, equal to those of the USA and the EU combined (see Table 5).

Climate change will become a common challenge for all countries. China has become the largest carbon dioxide emitter during the past decade, and will represent 28.3 per cent of the world's total emission by 2020, which is almost the total of all North countries and two-fifths of that of the South countries (see Table 6). Global carbon emissions are likely to peak between 2020 and
2030 and China will no doubt contribute more to the absolute mitigation of carbon than just reducing the relative emission intensity in its current commitment. IEA predictions show that it is likely to peak sometime between 2020 and 2030 if all countries cooperate in the launching of an energy and environmental revolution. Carbon emissions will drop sharply after that time, when global economic development is expected to reduce carbon emissions. ${ }^{4}$

The green industrial revolution will become the goal of the world. At its core is the desire to fundamentally change the worldwide economic development model and roadmap that has been in place since 1750 . In the twenty-first century, China will face its most important strategic opportunity to become an active participant of this green revolution and a leader of innovation. China will initiate innovative green action and implement green development strategies - it will synchronise its step with the rest of the world. China will strive to bring about its peak carbon emissions sometime in 2020-50, followed by a sharp decline.

\section{Per capita contribution and poverty alleviation}

The sustained high growth of China and India, both of which have populations numbering in the billions, could stimulate a shift from the 'great divergence era', which lasted for two centuries, to the 'great convergence era' of the twenty-first century, ${ }^{5}$ although the inequity coefficients of both countries will remain high. 


\begin{tabular}{lcccccc}
\hline & $\mathbf{1 9 5 0}$ & $\mathbf{1 9 7 0}$ & $\mathbf{2 0 0 0}$ & $\mathbf{2 0 1 0}$ & $\mathbf{2 0 2 0}$ & $\mathbf{2 0 3 0}$ \\
\hline The South & $\mathbf{2 0 . 5}$ & $\mathbf{1 7 . 1}$ & $\mathbf{1 3 . 5}$ & $\mathbf{1 8 . 1}$ & $\mathbf{2 4 . 1}$ & $\mathbf{3 4 . 4}$ \\
Developing Asian countries & 11.8 & 10.0 & 13.5 & 21.0 & 29.6 & 44.4 \\
China & 8.3 & 7.1 & 15.2 & 31.5 & 55.0 & 85.7 \\
India & 11.3 & 7.0 & 8.1 & 13.3 & 23.2 & 43.6 \\
\hline
\end{tabular}

Note The North countries $=100$.

Source Authors' own with data from Maddison (2010); Population Division of the Department of Economic and Social Affairs of the United Nations Secretariat (2010); data for 2020 and 2030 are the estimates of the authors.

We predict that in the next 20 years, the world will enter into an era of 'great convergence', largely because of the independent development experienced by the South. International inequity will be reduced in many areas, including education, ${ }^{6}$ health,${ }^{7}$ per capita GDP and per capita income with respect to other social indicators. The South and the North will converge in terms of education and health, driven by the globalisation of knowledge and politics, economics and education.

In the next 20 years, the income levels of all countries will converge. In 2010, the per capita GDP of the South was, by and large, one-sixth of the average of the North. However, with the rapid development of the South, its per capita GDP is expected to reach one-third of that of the North by 2030 . The income gap between the two groups will quickly narrow, with the per capita GDP catching-up indices of the two biggest countries in the South, China and India, likely to reach 85.7 per cent and 43.6 per cent of the North, respectively (see Table 7). China and India's economic growth will mitigate worsening income inequity (World Bank 2006).

We estimate that China's GDP growth will remain at 7-8 per cent from 2010 to 2030 (see Annex). As China's population records zero growth (below 2 per cent), China's per capita GDP growth will remain at 7 per cent or higher, which is 1.8 percentage points less than the period 1978-2010. Up to 2030, China's per capita GDP will be 4.2 times that of 2010 and 62.5 times that of 1978.

We have adopted three methods to calculate the US dollar value of per capita GDP from 2010 to 2030 and the catch-up coefficient of China's per capita GDP vis-à-vis the US per capita GDP. The first is the exchange rate method or market exchange rate method, taking into account China's nominal GDP average deflator and the changes in the exchange rate of the Chinese renminbi (RMB) to the dollar; the second is the PPP current price method adopted by the World Bank, taking into account the changes in the dollar price; the third is the PPP constant price adopted by Maddison, with the 1990 international dollar price as the benchmark.

No matter what method is used, the results unanimously indicate a convergence in the following decades. China's per capita GDP was 2.6-11.7 per cent of that of the USA in 2000; up to 2010 the percentage was $10-25$ per cent; and by 2020 , it will be $25-40$ per cent, which means China will be in for a para-high income period. By 2030 China's per capita GDP will be about half that of the USA, ${ }^{8}$ representing China's entry into the high-income stage (see Table 8).

Over the past three decades of reform and opening-up, China's greatest achievement has been its large-scale poverty reduction. The basic national conditions of China were not only a 'large population, a weak foundation to start out from and limited cultivated land' (Deng 1994: 164). But it was also the largest power with the greatest population living in poverty. If calculated according to the internationally accepted poverty line, that is, living on US $\$ 1$ per person per day, the number of people living below the international poverty line was probably as many as 860 million, with the international poverty occurrence of about 90 per cent. ${ }^{9}$ If calculated by the three international poverty lines of US $\$ 1$, US $\$ 1.25$ and US $\$ 2$, China's contribution to global poverty reduction has 95.1 per cent, 122 per cent and 951 per cent respectively over the period 
Table 8 China's per capita GDP and catch-up coefficient (2000-30)

\begin{tabular}{|c|c|c|c|c|c|c|}
\hline & 2000 & 2010 & 2015 & 2020 & 2025 & 2030 \\
\hline \multicolumn{7}{|c|}{ Exchange rate (current price) } \\
\hline China & 925 & 4,249 & 8,220 & 16,025 & 27,255 & 46,670 \\
\hline \multirow[t]{2}{*}{ USA } & 35,040 & 47,390 & 55,360 & 64,838 & 76,177 & 89,798 \\
\hline & 2.6 & 9.0 & 14.8 & 24.7 & 35.8 & 52.0 \\
\hline \multicolumn{7}{|c|}{ PPP (current price) (World Bank) } \\
\hline China & 2,305 & 7,164 & 11,137 & 17,448 & 25,063 & 36,246 \\
\hline \multirow[t]{2}{*}{ USA } & 35,040 & 46,626 & 50,554 & 54,955 & 59,926 & 65,566 \\
\hline & 6.6 & 15.4 & 22.0 & 31.8 & 41.8 & 55.3 \\
\hline \multicolumn{7}{|c|}{ PPP (1990 price) (Maddison) } \\
\hline China & 3,335 & 7,822 & 10,748 & 14,883 & 18,896 & 24,153 \\
\hline \multirow[t]{2}{*}{ USA } & 28,433 & 30,589 & 33,166 & 36,053 & 39,314 & 43,014 \\
\hline & 11.7 & 25.6 & 32.4 & 41.3 & 48.1 & 56.2 \\
\hline
\end{tabular}

Note (1) For the GDP aggregate calculated using the exchange rate method, 2010-20, China's GDP real growth will be 8 per cent, GDP deflator will be 3 per cent, appreciation of RMB to the dollar will be 3 per cent, US GDP real growth will be 2 per cent, and GDP deflator will be 2 per cent; for 2020-30, China's GDP real growth will be 7 per cent, GDP deflator will be 2 per cent, appreciation of RMB to the dollar will be 2 per cent, US GDP real growth will be 2 per cent, GDP deflator will be 2 per cent. (2) For the GDP aggregate calculated using the PPP current price method, 2010-230, the GDP deflator will be 2.5 per cent. (3) For the GDP aggregate calculated using the PPP constant price, 2010-20, China's GDP growth will be 7 per cent, and for 2020-30, China's GDP growth will be 5 per cent; US GDP growth will be 2.5 per cent for 2010-30.

Source Authors' own with data from World Bank (2011); Maddison (2010); Population Division of the Department of Economic and Social Affairs of the United Nations Secretariat (2010).

1981-2005 (see Table 9). According to the recent UN Millennium Development Goal (MDG) report, the goal of cutting extreme poverty by half is expected to be realised by 2015. The population living on less than US $\$ 1$ a day was 1.8 billion in 1999, reduced to 1.4 billion by 2005 . The report attributes this mainly to the contributions made by China.

The relative poverty rate of developing countries decreased from 46 per cent to 27 per cent from 1990 to 2005 . By 2015, the total poverty occurrence rate is expected to drop below 15 per cent (United Nations 2011). According to this trend, the poverty occurrence rate in developing countries will drop below 10 per cent by 2020 and then below 5 per cent by 2030 (see Table 10), basically eliminating international absolute poverty. Therefore, the United Nations and the international community will have to formulate a further MDG for the second stage (2015-30). With the close cooperation of all governments and effective international governance, we may well see the realisation of this dream.

The world as a whole is likely to enter a stage of high human development. According to a new computation method developed by United Nations Development Programme (UNDP), China's HDI was 0.663 in 2010 (an upper-middle level ranking) while the world's HDI was 0.624 (a lower-middle level ranking). By 2020 global HDI will be at 0.696 , close to the upper levels, while China's HDI will be 0.750 , well within the upper level.

In terms of the composition of HDI, global per capita GDP will reach US $\$ 14,000$ by 2020 ; the average number of years of education will reach eight, with the expected number being 13 years; and the expected mean life expectancy will be 75 years. For China, these four indicators will be US $\$ 14,000$, ten years, 14 years, and 77.5 years respectively. By 2030, global HDI will be 0.703 , 


\begin{tabular}{|c|c|c|c|c|c|c|}
\hline & \multicolumn{3}{|c|}{ Less than one dollar } & \multicolumn{3}{|c|}{ Less than 1.25 dollars } \\
\hline & China & India & World & China & India & Total \\
\hline 1981 & 730.4 & 296.1 & 1535.3 & 835.1 & 420.5 & 1913.4 \\
\hline 1987 & 412.4 & 285.3 & 1228.3 & 585.7 & 428 & 1718.2 \\
\hline 1990 & 499.1 & 282.5 & 1303.2 & 683.2 & 435.5 & 1817.5 \\
\hline 1996 & 288.7 & 271.3 & 1132.8 & 442.8 & 441.8 & 1672 \\
\hline 1999 & 302.4 & 270.1 & 1146 & 446.7 & 447.2 & 1694.8 \\
\hline 2002 & 244.7 & 276.1 & 1090.2 & 363.2 & 460.5 & 1629.4 \\
\hline 2005 & 106.1 & 266.5 & 879 & 2077 & 455.8 & 1399.8 \\
\hline Reduction & -624.3 & -29.6 & -656.3 & -627.4 & 35.3 & -513.6 \\
\hline Contribution (\%) & 95.1 & 4.5 & 100.0 & 122.0 & -6.9 & 100.0 \\
\hline
\end{tabular}

Source Author's calculation based on Chen and Ravallion (2008).

recognised as a high level, while China's HDI will be 0.776 and is likely to exceed 0.800 between 2040 and 2050. In terms of HDI indicators, by 2030 global per capita GDP will reach US\$19,000; the average length of education will be 9.5 years; expected education will be 14 years; the mean life expectancy will be 79 years. These four indicators for China will be US $\$ 23,000$, ten years, 16 years, and 80 years, respectively.

It took China 25 years to enter the lower-middle development level from an extremely low level. It took a further 20 years to leave that level and enter the upper-middle level. By 2015, China will enter a stage of high human development. In 20 years' time, China will enjoy a period of extremely high human development.

No matter what method is used, China's per capita GDP by 2030 will be approximately 50 per cent of the USA figure. However, its HDI will be approximately 85 per cent of that of the USA; the gap in life expectancy will be narrowed to only 1.3 years. The expected years of schooling will exceed the figure for the USA. This information is useful to determine which level China will reach in the world and when (it is important to note that the HDI of the USA is not the highest worldwide).

Many countries increase their HDI by relying on the growth of their GDP per capita. China's per capita GDP growth between 1980 and 1990 contributed to 79.8 per cent of HDI growth. It decreased somewhat to 62.6 per cent between 1990 and 2000 and a similar level between 2000 and 2010. In our projection, its contribution will be less than 50 per cent for the first time between 2010 and 2020 and we expect it to be as low as 36.0 per cent between 2020 and 2030. In

Table 10 International poverty occurrence rate (1990-2030)

\begin{tabular}{lccccc}
\hline & $\mathbf{1 9 9 0}$ & $\mathbf{2 0 0 5}$ & $\mathbf{2 0 1 5}$ & $\mathbf{2 0 2 0}$ & $\mathbf{2 0 3 0}$ \\
\hline China & 60.2 & 15.9 & $<5$ & 1 & \\
India & 51.3 & 41.6 & 22 & 15 & $<10$ \\
Other developing countries & 46.0 & 27.0 & $<15$ & $<10$ & $<5$ \\
\hline
\end{tabular}

Note The international poverty occurrence rate is calculated according to the international absolute poverty line (\$1.25 per person per day). Source Authors' own with data from United Nations (2011); National Bureau of Statistics (2011); World Bank (2011); the data for 2020 and 2030 are the estimates of the authors. 
Table 11 HDI for China, the USA and India and catch-up coefficient (1980-2030)

\begin{tabular}{llllllll}
\hline & $\mathbf{1 9 8 0}$ & $\mathbf{1 9 9 0}$ & $\mathbf{2 0 0 0}$ & $\mathbf{2 0 0 5}$ & $\mathbf{2 0 1 0}$ & $\mathbf{2 0 2 0}$ & $\mathbf{2 0 3 0}$ \\
\hline China & 0.368 & 0.460 & 0.567 & 0.616 & 0.663 & 0.750 & 0.776 \\
USA & 0.810 & 0.857 & 0.893 & 0.895 & 0.902 & 0.919 & 0.926 \\
India & 0.320 & 0.389 & 0.440 & 0.482 & 0.519 & 0.559 & 0.564 \\
China/USA & 0.45 & 0.54 & 0.63 & 0.69 & 0.74 & 0.82 & 0.84 \\
India/USA & 0.40 & 0.45 & 0.49 & 0.54 & 0.58 & 0.61 & 0.61 \\
\hline
\end{tabular}

Source Authors' own with data from United Nations Development Programme (2011); data for 2020 and 2030 are the estimates of the authors.

contrast, China will achieve higher HDI by relying more and more on an increase in the areas of education and health. Between 2020 and 2030, education will surpass GDP per capita to become the key factor of China's HDI growth and it will contribute more than 50 per cent during that period of time.

\section{The logic of China's development}

From the mid-1990s to the mid-twentieth century, China lagged behind in the drive for worldwide modernisation and was subject to bullying. In the latter half of the twentieth century, China played a successful game of catch-up, advancing from behind to be at the forefront internationally. In the twenty-first century, China will catch up with and overtake the most developed capitalist country in the world, the USA. This will occur not only because of China's one billion population, its 9.6 million square metres of territorial land, and its several thousand years of civilisation, culture and written language, but also because China has a unique and superior socialist system - superior both in terms of its socialist political system, and in terms of the advantages of its socialist market economy.
What do we predict for China's future development? The records on China's development both at home and abroad over the past few decades show that neo-classical growth theory is, in reality, unable to predict the development of China's economy. The predictions of many different economic models, no matter how precise or complicated, have been proven far from accurate, with most models significantly underestimating the potential of China's development.

In contrast, Chinese leaders have offered accurate forecasts regarding the prospects of China's development. These leaders did not rely on specialised knowledge and tools, but rather on their political wisdom and wealth of experience. We have looked to their experience in making our predictions and formulating our ideas for 2030. We have pinpointed the crucial variables that will influence China's long-term development and carried out an in-depth analysis of the major problems and contradictions. Thus, we have conceived China's future in a bold and forwardlooking manner, based on both economic analysis and long-term development experience, with a

Table 12 Contributing factors to China's HDI (1980-2030)

\begin{tabular}{lcccc}
\hline & Income & Education & Health & Interactive items \\
\hline $1980-1990$ & 79.8 & 22.4 & 6.0 & -8.3 \\
$1990-2000$ & 62.6 & 31.9 & 9.6 & -4.1 \\
$2000-2010$ & 63.9 & 30.9 & 8.5 & -3.2 \\
$2010-2020$ & 49.4 & 44.0 & 8.3 & -1.7 \\
$2020-2030$ & 36.0 & 50.7 & 12.8 & 0.5 \\
\hline
\end{tabular}

Source Authors' own with data from United Nations Development Programme (2011); data for 2020-2030 are the estimates of the authors. 
focus on the orientation of China's future development strategy. Although we are faced with many uncertainties regarding the future, we are most concerned with the following questions: What is the most significant opportunity for the future? Which prediction is the most accurate and how can our ideas be put into practice and evaluated in the future?

China is conscientious, not reckless in its development; its development is purposeful and not spontaneous, planned and not disorderly. China's development path is constituted by the integration of three trends: a natural (objective) trend, market-driven development under the guidance of plans, and development under the guidance of planning and strategy. To predict China's development, it is necessary to take into account the interactions among the three trends.

An objective trend is the result of spontaneous behaviour subject to society. This reflects the interaction between the indicators and the development stage; that is, the trend changes with an increase in per capita income or per capita GDP, and has nothing to do with the variables of government policies. With regard to the value of an objective trend, it is necessary to consider the various influencing factors, including the basic national conditions, the stage of development and the development potential, as well as taking into account all uncertainties and restraining factors. Only then can forward-looking predictions and scientific calculations be made.

A market-driven value is subject to guidance by government policies formulated in the planning process. Policies are geared towards stimulating market initiatives and mobilising social forces in order to accelerate the realisation of state objectives. However, in many circumstances, nongovernmental and market forces far exceed the anticipation and expectations of government. Of course, the objectives (to some degree) are also subject to the impact of external resistance in the process of development, and are discounted to an extent. Thus, the market-driven value is reduced, even to zero in some cases.

Nevertheless, due to the constraint of the third factor, plan guidance value, these objectives will ultimately have their bottom line.

The plan guidance value is the government influence on the real development trend indicators by reasonably allocating public resources and effectively employing public forces to either accelerate development (developmental indicator) or to limit the development trend (control type indicator). It reflects the role of the visible hand of government planning. Plan guidance value determines the intensity of the political will on the one hand and on the other it is based on the drawing capacity of public resources (financial, material and human resources), the capacity of mobilisation, and the allocation capacity.

The above three trends also reflect China's superiority regarding both its development and its political and economic system. In terms of development, China has an advantage in being a late-comer, and in being a large-scale power. China possesses significant development potential, and has fairly long periods during which development opportunities are plentiful. China has the momentum and conditions for high-speed development. In terms of its political and economic system, China has the advantage of the 'invisible hand' of the market, which is full of vitality and creativity, and the advantage of the 'visible hand' in terms of long-term development strategy and planning. The organic combination of the two, in turn, will accelerate the speed of development while at the same time guiding the direction of development.

\section{Conclusion: China's efforts to build a world of harmony}

The nearly 200 years of modern economic growth represents an era of 'great divergence ${ }^{\text {'10 }}$ with the North-South gap constantly growing wider. It is a history of inequity, injustice and unfairness, with the North dominating the world economic order. We hold that the twenty-first century is the century in which Ghina will make huge contributions to human development. What are these significant contributions? China's role and position in the world arena enables China to be an advocate for a 'world of great harmony', an active participant and builder of a 'world of great harmony', and the biggest contributor to a 'world of great harmony'.

China will become the biggest engine of growth of the world. China will become the world's biggest market, with increasingly strong positive externalities and a positive spillover effect. It will make increasingly significant contributions 
to the market, ${ }^{11}$ trade, ${ }^{12}$ employment and investment. ${ }^{13}$ China is travelling towards development, and actively promotes fairer and more just international economic and political orders. China will make positive contributions to protecting the global environment, tackling global climate change, conserving energy, reducing emissions and promoting a green industrial revolution.

China will become the largest contributor of development aid. China has formulated a new foreign aid programme based on its existing scheme. ${ }^{14}$ This programme requires three steps. The first step is to bring the amount of foreign aid as a proportion of GDP to 0.3 per cent by 2015; the second step is to increase it to 0.5 per cent by 2020; the third step is to raise it to 1 per cent or above by 2030 . This will actively encourage other world powers, high-income countries, and emerging economies to increase their development aid in proportion to their GDPs and to expand the global aid programme. It will also push the UN and other international organisations to formulate an MDG for 2015-30. The targets of China's foreign aid programme are fundamentally different. China mainly aids the least developed and developing countries, benefiting those countries in the South that are home to 80 per cent of the world's population. As the biggest developing country, China has actively promoted South-South cooperation, trade and investment liberalisation, and fair and even development between the South and the North.

China will become a leader in the worldwide process of great change. China is resolutely opposed to hegemony and power politics, and persists in the principle of equality for all countries, big or small, strong or weak, rich or poor. China respects the right to free choice for people of all countries. China has made and will continue to make worldwide contributions to achieve global common wealth and common prosperity, and it will undertake even greater responsibilities. The rise of China benefits the world as a whole. However, such development also represents greater expectations and responsibilities (Ban 2010). The rapid rise of China has not only changed the pattern of interpower rivalries but also the role of China within the international system. This has created unparalleled historical development opportunities for China.

\section{Contemporary China is experiencing} unprecedented economic development, social transition and social change. The contemporary world is experiencing unprecedented development, changes and adjustment. Peace, development and cooperation are now mainstream, and have created favourable conditions for common efforts to build a world of great harmony. For China, a foremost objective is to safeguard world peace, prevent any further world wars, and to prevent wars among the world powers so as to maintain an internationally peaceful environment for the following 20 years (or longer). It is then necessary to promote common development, help the countries of the South accelerate their development, and narrow the various inequalities between the South and the North. Such measures will help to achieve the internationalisation and globalisation of common wealth. It is necessary to strengthen mutually beneficial cooperation in order to establish a fairer and more just global governance structure; the key word here is mutual. It is essential to change the current unfair, unjust and unequal practices. Peace is the basic condition for development; cooperation is the basic channel for promoting development; and development is the basic goal of peace and cooperation. 
Annex Potential economic growth rate of China (2011-30)

\section{State space model}

According to the basic theory of Phillips curve and Okun's Law, we can estimate the output gap and Non-accelerating Inflation Rate of Unemployment (NAIRU) through the dynamic system of output, inflation and unemployment rate (Apel and Jansson 1999). We therefore construct a state space model, treating potential output and unemployment rate as the unobserved variables (state variables), to estimate China's potential output. The basic structure of the model is as follows:

Equation for Phillips curve:

$\pi_{t}=\rho \pi_{t-1}+\sum_{j=0}^{h} \eta_{j}\left(u_{t-j}-u_{t-j}^{n}\right)+\varepsilon_{t}^{1}$

Here $\pi_{t}$ dicates inflation rate, $u_{t}$ indicates real unemployment rate, $u_{t}^{n}$ indicates NAIRU, $\left(u_{t}-u_{t}^{n}\right)$ indicates unemployment rate gap and $\varepsilon_{t}^{1}$ is the random error. Phillips curve serves as a constraint of the unobserved-components system (UC Model). The unobserved unemployment gap can be expressed in the model and can be estimated together with the parameters of the model.

Equation for Okun's Law:

$y_{t}-y_{t}^{p}=\sum_{l=0}^{k} \varphi_{l}\left(u_{t-l}-u_{t-l}^{n}\right)+\varepsilon_{t}^{2}$

Here $y_{t}$ indicates the logarithm of real output, $y_{t}^{p}$ indicates the logarithm of the potential output, $\left(y_{t}-y_{t}^{p}\right)$ indicates the output gap, $\varepsilon_{t}^{2}$ is random error and $\varphi_{l}$ is unknown parameter. Equation (2) treated potential output as an endogenous variable and ensures the estimations of unemployment gap and output gap are consistent with each other.

Equation for potential output:

$y_{t}^{p}=\alpha+y_{t-1}^{p}+\varepsilon_{t}^{3}$
Here $\varepsilon_{t}^{3}$ is random error and $\alpha$ is unknown parameter. Equation (3) described the dynamic features of potential output, where potential output was assumed to follow a random walk with drift.

Equation for unemployment rate gap:

$u_{t}-u_{t}^{n}=\delta_{0}+\delta_{1}\left(u_{t}-u_{t}^{n}\right)+\varepsilon_{t}^{4}$

Here $\varepsilon_{t}^{4}$ is random error and $\delta_{0}$ and $\delta_{1}$ are unknown parameter. Equation (4) described the dynamic features of unemployment rate gap, which was assumed a first order auto regression process.

Equation (1) to (4) form a state space model, among which equations (1) and (2) are measure equations (or signal equations) while equations (3) and (4) are transition equations (or state equations).

\section{Model estimation}

When estimating the model, we use the Consumption Price Index to measure $\pi_{t}$, and use real GDP to measure $y_{t}$. As China's unemployment statistics cannot fully reflect the unemployment of Chinese society, we treat $\left(u_{t}-u_{t}^{n}\right)$ as a state variable. The interval for the sample data was between 1952-2008. To ensure the validity of the estimation result, we apply non-negative constraints to the variance of $\varepsilon_{t}^{1}, \varepsilon_{t}^{2}, \varepsilon_{t}^{3}$ and $\varepsilon_{t}^{4}$ by using the natural exponential, which are expressed as $\mathrm{e}^{\mathrm{g}_{1}}, \mathrm{e}^{\mathrm{g}_{2}}$, $\mathrm{e}^{\mathrm{g}_{3}}$ and $\mathrm{e}^{\mathrm{g}_{4}}$.

\begin{tabular}{lcccccccccc}
\hline \multicolumn{2}{l}{ Table $\mathrm{Al}$ Estimation result of the main parameter of the model } \\
Parameter & $\rho$ & $\eta_{0}$ & $\varphi_{0}$ & $\alpha$ & $\delta_{1}$ & $g_{1}$ & $g_{2}$ & $g_{3}$ & $g_{4}$ \\
Estimation & 0.74 & -00.84 & -1.47 & 0.58 & 0.08 & -6.44 & -6.97 & -7.71 & -6.97 \\
P Value & 0.00 & 0.00 & 0.00 & 0.00 & 0.00 & 0.00 & 0.00 & 0.00 & 0.00 \\
\hline
\end{tabular}




\begin{tabular}{lccc} 
1952-2010 & Potential growth rate & Average negative deviation & Average positive deviation \\
$1981-2010$ & 0.08 & -0.02 & 0.01 \\
$2001-05$ & 0.11 & & \\
$2006-10$ & 0.10 & Lower bound & Upper bound \\
& Potential growth rate & 0.07 & 0.10 \\
$2011-15$ & 0.09 & 0.06 & 0.09 \\
$2011-30$ & 0.08 & Projection results & \\
\hline & & & Upper bound (\%) \\
$2011-15$ & Potential growth rate (\%) & Lower bound (\%) & 10.2 \\
$2016-20$ & 8.9 & 6.9 & 9.7 \\
$2021-25$ & 8.4 & 6.4 & 8.7 \\
$2026-30$ & 7.4 & 5.5 & 8.2 \\
$2011-30$ & 6.9 & 5.0 & 9.2
\end{tabular}

\section{Notes}

* School of Public Policy and Management, Tsinghua University. Corresponding author: Yuning Gao,gao_yuning@tsinghua.edu.cn

1 An estimation of population growth and population structure is a core clue to predict the long-term development of both China and the world, and is the basis for accurate predictions. First, we make a prediction regarding the natural growth trends for all indicators using a linear model. Second, an adjustment is made for the estimated linear values for 2015 or 2020, based on already published development plans, and judgements are then made regarding the long-term trend for 2030 using a rule-of-thumb.

2 This prediction is similar to the 2007 prediction by Nobel laureate Robert Fogel (2007), who said that by 2040 the economic aggregates of the USA, the EU (15 countries), India, China and Japan will be 14 per cent, 5 per cent, 12 per cent, 40 per cent and 2 per cent, respectively.

3 Green energy has three meanings: cleaning of traditional energy, renewable energy, and the highly efficient use of energy.

4 If the atmosphere's global hothouse gas density is stabilised at 450ppm $\mathrm{CO}_{2}$ equivalent (the so-called ' 450 scenario'), then global $\mathrm{CO}_{2}$ emissions will peak at 30.7 billion tonnes (carbon equivalent) by 2020, $\mathrm{CO}_{2}$ emissions will drop to 24-26 billion tonnes (carbon equivalent) by 2030, and to ten billion tonnes (carbon equivalent) by 2050, about half that of 1990 (20.9 billion tonnes, carbon equivalent) (International Energy Agency 2009: 172; 2011).

5 According to the calculations of the World Bank, since 1950, the weighted inequality (Gini coefficient) has been in a continuous decline, mainly because income has been growing in population-dense countries such as China and India. However, if China and India are excluded, international inequality (Gini coefficient) increased after the 1980s. Since 1950, the un-weighted country inequality (Gini coefficient) has assumed a long-term upward trend. However, more recently, especially in the 1990s, international inequality was reduced, mainly because of an increase in the income of China and South Asia (see World Bank 2006).

6 According to calculations of the World Bank, the global average years of education received increased from 3.4 years to 6.3 years in 2000 , 
while the education inequity variant coefficient dropped from 0.739 to 0.461 (see World Bank 2006).

7 According to a study by the World Bank, while the world's mean life expectancy has increased, the inequity in the mean life expectancy among the countries has been reduced, with the variant coefficient declining from 0.233 in 1960 to 0.194 in 2000 (see World Bank 2006).

8 This method is different from the method used by economists, which measures the dollar value of per capita GDP using constant price and constant exchange rate methods. The use of the exchange rate method underestimates the real purchasing power of RMB and accompanied with economic globalisation and integration, the exchange rate of the RMB to the dollar will assume an upward trend. Therefore, using the exchange rate method, the dollar value of China's per capita GDP would move to a long-term convergence towards PPP current price and PPP constant price. By 2030 the dollar value of China's per capita GDP would be approximately 50 per cent of the USA according to the various methods of calculation.

9 This is the authors' calculation based on the World Bank data. If calculated by the one dollar criterion, the World Bank estimated that the number of poor people in China in 1981 was 730 million, 430 million more than India, which was ranked second with 296 million. But by 2002, China was no longer the biggest country with the biggest poor population, with the absolute figure of poor population put at 240 million. India rose to the number one large power with the biggest poor population of 276 million (see Chen and Ravallion 2008).

10 Since 1820, while the world's per capita GDP has been growing, the long-term trend has been a growing disparity in income. According to calculations and analysis by Angus Maddison, this manifests itself in a disparity among the various larger regions, which was less than 3:1 in 1820, but reached 16:1 in 1992. It is also manifested in the gap among different countries (between dominant countries and the countries with the poorest performances), which exceeded 3:1 in 1820 but reached 72:1 in 1992. Only a small group of lagging countries caught up after the Second World War and convergence occurred (see Maddison 1995). After the Second World War, per capita GDP in the South reduced compared with the per capita GDP of the North, from 20.5 per cent in 1950 to 17.1 per cent by 1970 , and to 13.5 per cent by 2000 . Per capita GDP in developing Asian countries reduced from 11.8 per cent in 1950 to 10.0 per cent by 1970 , but increased to 13.5 per cent by 2000, thanks to the economic take-off of Asia's Four Little Dragons, China, India and Southeast Asia.

11 China's average contribution was 14.6 per cent in 2001-09 to become the number one contributor to economic growth.

12 According to statistics from United Nations Trade and Development Conference (UNTDC), China's percentage in goods import trade in the world rose from 4.4 per cent to 8 per cent for 2002-09 and its percentage in the world's service import trade rose from 2.9 per cent to 4.9 per cent.

13 In 2002-09, the average annual contribution to global FDI inflow reached 3 per cent and outflow, 5.5 per cent.

14 China's foreign aid is made up of three categories: free aid, interest-free loans, and preferential loans. There are mainly eight forms of aid: complete plants, general materials, technical cooperation, cooperation in human resources development, medical teams, emergency humanitarian aid, volunteers, and debt reduction and exemption. According to the White Paper on China's foreign aid (Information Office of the State Council 2011), China has provided aid of 256.29 billion yuan, including 106.2 billion yuan free aid, 76.54 billion yuan interest-free loans, and 73.55 billion yuan of preferential loans, accounting for 41.4 per cent, 29.9 per cent and 28.3 per cent, respectively, in total foreign aid. China's foreign aid funds experienced rapid growth, with its average growth for 2004-09 being 29.4 per cent. By the end of 2009, China had signed debtwriting off protocols with 50 countries in Africa, Asia, Latin America, the Caribbean, and Oceania, writing off 380 debts, amounting to 25.58 billion yuan (equal to 17 per cent of the total aid loans). 


\section{References}

Apel, Mikael and Jansson, Per (1999) 'A Theoryconsistent System Approach for Estimating Potential Output and the NAIRU', Economics Letters 64.3, Elsevier: 271-5

Ban, K.-M. (2010) 'Let China be the Country to Show the Way Ahead', UN Secretary General Ban Ki-Moon's Speech at Nanjing University, Nanjing, www.un.org/News/Press/docs/2010/ sgsm 13219.doc.htm (accessed 31 October 2010)

Carbon Dioxide Information Analysis Center (2010) Fossil-Fuel $\mathrm{CO}_{2}$ Emissions Database, http://cdiac.ornl.gov/trends/emis/overview_ 2010.html (accessed 14 November 2012)

Chen, S. and Ravallion, M. (2008) The Developing World is Poorer than we Thought, But No Less Successful in the Fight Against Poverty, Policy Research Working Paper Series 4703, Washington DC: World Bank, http://go.worldbank.org/EXMW4AJY40 (accessed 1 August 2008)

Deng, X. (1994) 'Uphold the Four Cardinal Principles', in Selected Works of Deng Xiaoping, Vol. II, Beijing: People's Publishing House

Fogel, R. (2007) Capitalism and Democracy in 2040: Forecasts and Speculations, NBER Working Paper 13184, Cambridge MA: National Bureau of Economic Research

Information Office of the State Council (2011) China's Foreign Aid, White Paper, April, Beijing: Information Office of the State Council, http://english.gov.cn/official/2011-04/21/ content_1849913.htm (accessed 21 April 2011)

International Energy Agency (2012) World Energy Outlook 2012, Paris: International Energy Agency

International Energy Agency (2009) World Energy Outlook 2009, Paris: International Energy Agency

Maddison, A. (2010) Statistics on World Population, GDP and Per Capita GDP, 1-2008 AD, www.ggdc.net/maddison/Historical_Statistics/ horizontal-file_02-2010.xls (accessed 18 October 2012)
Maddison, A. (2001) The World Economy: A Millennial Perspective, Paris: OECD Development Centre

Maddison, A. (1995) Monitoring the World Economy 1820-1992, Paris: OECD Development Centre

McKinsey Global Institute (2011) Urban World: Mapping the Economic Power of Cities, McKinsey Global Institute, www.mckinsey.com/insights/ urbanization/urban_world (accessed 4 April 2011)

National Bureau of Statistics (2011) China Statistical Abstract 2011, Beijing: China Statistics Press

National Intelligence Council (2008) Global Trends 2025: A Transformed World, Washington DC:

National Intelligence Council, www.fas.org/irp/ nic/2025.pdf (accessed 26 December 2012)

Population Division of the Department of Economic and Social Affairs of the United Nations Secretariat (2010) World Population Prospects: The 2010 Revision, http://esa.un.org/ unpd/wpp/index.htm (accessed 1 October 2011)

UNCTAD (2011) UNCTAD STAT, (Foreign direct investment), http://unctadstat.unctad.org/ ReportFolders/reportFolders.aspx?sRF_Active Path=p,5\&sRF_Expanded=,p,5 (accessed 1 October 2011)

UNCTAD (2010) World Investment Report 2010: Investing in a Low-Carbon Economy, New York and Geneva: United Nations Conference on Trade and Development, http://unctad.org/en/ docs/wir2010_en.pdf (accessed 29 July 2010)

United Nations (2011) Millennium Development Goal Report 2011, New York: United Nations

United Nations Development Programme (2011) UNDP 2010-2012 Development Projects, https://data.undp.org/dataset/UNDP-20102012-Development-Projects/mz96-avwa (accessed 4 April 2014)

World Bank (2011) World Development Open Data, http://data.worldbank.org/ (accessed 1 October 2011)

World Bank (2006) World Development Report 2006: Equity and Development, (Chinese edition), Beijing: Tsinghua University Press 